\title{
AVALIAÇÃO E DETERMINAÇÃO DE PARÂMETROS REPRODUTIVOS DE RATOS WISTAR (Mus norwergicus albinus) SUBMETIDOS A TRATAMENTO COM AVERMECTINAS
}

\author{
PARAMETERS EVALUATION AND DETERMINATION OF \\ REPRODUCTIVES WISTAR RATS (Mus norwergicus albinus) \\ UNDER AVERMECTINS TREATMENT
}

\author{
Alessandra FOLADOR \\ Orientador: Professor Dr. Luiz Cláudio FERNANDES \\ Departamento de Fisiologia - UFPR
}

\begin{abstract}
RESUMO
As avermectinas são utilizadas amplamente no tratamento de endo e ectoparasitoses. $O$ efeito destas drogas sobre o aparelho reprodutor masculino tem sido pouco estudado. Nosso trabalho objetivou estudar se as avermectinas abamectina, doramectina e ivermectina teriam algum efeito sobre os órgãos, tecidos e hormônios envolvidos na reprodução. Ratos machos Wistar foram tratados com as diferentes avermectinas na dose de $1 \mathrm{mg} / \mathrm{kg}$, subcutaneamente e no controle administrado o veículo. Os animais foram sacrificados na $1^{\mathrm{a}}, 3^{\mathrm{a}}, 5^{\mathrm{a}}$ e $8^{\mathrm{a}}$ semana pós inoculação do fármaco e parâmetros morfológicos e bioquímicos foram determinados. A massa do testículo, próstata, vesículas seminais, epidídimo e hipófise não foi diferente entre os grupos em todos os períodos estudados. $\mathrm{Na}$ análise da motilidade, vigor e morfologia espermática e na histologia do parênquima testicular não foi detectada qualquer aberração quando comparada ao controle em todas as semanas de estudo. O conteúdo epididimário ao ser submetido ao SDS-PAGE não revelou qualquer alteração no padrão eletroforético das proteínas

entre os grupos estudados comparados ao controle. A determinação bioquímica sérica da glicemia e dos hormônios FSH, LH e Testosterona Total também mostrou não ser diferente entre os grupos estudados e controle. A responsividade do parênquima testicular incubado com hCG foi investigada através da produção da testosterona e esta não foi diferente entre todos os grupos estudados. Os dados sobre a evolução temporal da massa corpórea mostrou que os animais tiveram um ganho de massa corporal igual ao controle, exceto o grupo tratado com ivermectina, o qual teve um ganho significativo $(\mathrm{p}<\mathrm{O}, \mathrm{O})$ a partir da $3^{\mathrm{a}}$ semana e esta diferença manteve-se até o final do período de estudo. Interessantemente, este ganho de massa corporal não foi provocado pelo aumento da ingestão alimentar. Nossos resultados sugerem que o tratamento com estas avermectinas não promovem qualquer alteração nos parâmetros reprodutivos estudados e a ivermectina foi capaz de induzir ganho de massa corporal sem alterar a ingestão alimentar.
\end{abstract}

\begin{abstract}
Avermectins are widely used to treat endo and ectoparasitoses. The effect of such drug on male reproductive system is poorly studied. Our research aimed to study if the avermectins abamectin, doramectin and ivermectin would have any effect on organs, tissues and hormones involved in the reproduction. Male Wistar rats were treated with each different avermectins in the dose of $1 \mathrm{mg} / \mathrm{kg}$, subcutaneously, and in the control was administered the vehicle. The animals were sacrified in the $1^{\text {st }}, 3^{\text {rd }}$ $5^{\text {th }}$ and $8^{\text {th }}$ week post inoculation of the drug morphological and biochemical parameters were evaluated. The testes, prostate, seminal vesicles, epididymis and hipophysis mass were not different between the groups in whole period studied. Analysis of motility, vigor sperm morphology and the histology of testicular parenchyma did not detect any aberration as compared to control in the weeks studied. The epididymis content submitted to SDS-PAGE did not reveal any alteration on the electrophoresis of proteins between

the studied groups compared to control. The biochemical serum measurements of glycemia, LH, FSH hormones and total testosterone also not shown any difference between the experimental and control groups. The responsiveness of testicular parenchyma incubated with $\mathrm{hCG}$ were investigated by testosterone production and there was no difference in all groups studied. The data about the mass weight evolution showed gain in the body weight identical to the control group, except in the ivermectin group, which had a significant increase in the body weight $(\mathrm{p}<0.05)$, starting at the $3^{\text {rd }}$ week and this difference was kept through the experiment. interesting, this gain in body weight was not induced by increase in the food intake. Our results suggest that the treatment with these avermectins did not provoke any alteration in the reproductive parameters studied and the ivermectin was able to induce increase in the body weight without changing the rate of food intake.
\end{abstract}

